\title{
Parametric modeling and simulation of photovoltaic panels with earth water heat exchanger cooling
}

Sanjeev Jakhar, Manoj S. Soni* and Nikhil Gakkhar

\author{
*Correspondence: mssoni@ \\ pilani.bits-pilani.ac.in \\ Center for Renewable \\ Energy and Environment \\ Development (CREED), \\ Department of Mechanical \\ Engineering, Birla Institute \\ of Technology and Science, \\ Pilani, Rajasthan 333031, \\ India
}

\begin{abstract}
Photovoltaic (PV) systems work efficiently up to a certain cell temperature and exhibit efficiency losses and long-term degradation if the cell temperature exceeds a certain limit. The rise in temperature can be controlled with the help of cooling techniques to maintain cell temperature within limit. In the current research, a novel cooling technique termed earth water heat exchanger (EWHE) is designed and simulated by varying its operating parameters, which includes mass flow rate, length, pipe materials, and diameter of buried pipe. Results showed that peak PV panel temperature goes up to $79.31{ }^{\circ} \mathrm{C}$ without any cooling and drops to $47.13^{\circ} \mathrm{C}$ with the help of EWHE cooling for optimum flow rate of $0.018 \mathrm{~kg} / \mathrm{s}$. At this flow rate, with decrease in panel temperature, the PV power also increased by $23.16 \mathrm{~W}$ with EWHE cooling. The comparative study between three different EWHE pipe material shows that the performance of coupled (PV/T + EWHE) system hardly depends on the properties of these materials. It is also observed that there is an inverse correlation between the EWHE pipe length. The variation in pipe diameter shows that the PV temperature decreases with an increase in pipe diameter. The PV/T system along with EWHE may be used for the purpose of PV power plants cooling in the hot and semi-arid regions of western Gujarat and Rajasthan (India), where solar irradiation is ample and ambient temperatures are very high.
\end{abstract}

Keywords: Photovoltaic, Solar, earth water heat exchanger, TRNSYS (v17.0), Modeling, Renewable energy

\section{Background}

Solar energy is considered as one of the most promising renewable energy sources due to the fact that it is widely available all over the world and is being used to generate electricity (Ummadisingu and Soni 2011; Gakkhar et al. 2016). PV systems are commercially proven technology for electrical power generation from solar radiation. However, only $10-20 \%$ of incident solar radiation is converted into electrical energy, while the remaining radiation is absorbed as heat (Ozgoren et al. 2013). The absorbed radiation which is converted into heat results in an increase in the PV cells operating temperature. The rise in cell temperature beyond certain limit adversely impacts the efficiency and the life span of the cell (Jakhar et al. 2016b, c; Royne et al. 2005; Cabo et al. 2016). In fact, the PV electrical efficiency is highly dependent on the cell-operating temperature, and decreases

(c) 2016 The Author(s). This article is distributed under the terms of the Creative Commons Attribution 4.0 International License (http://creativecommons.org/licenses/by/4.0/), which permits unrestricted use, distribution, and reproduction in any medium, provided you give appropriate credit to the original author(s) and the source, provide a link to the Creative Commons license, and indicate if changes were made. 
with increasing temperature. From the literature review, it is observed that above a certain limit, the efficiency decreases by $0.45 \%$ per unit rise in cell-operating temperature (Du et al. 2013). Therefore, PV temperature control with the help of cooling is necessary for its better performance. The literature discusses the work carried out on different PV systems and cooling techniques. One of the cooling technique, where thermal collectors are attached on the back side of PV panels to produce both electrical energy and thermal energy, is called photovoltaic/thermal (PV/T) cooling system (Chow 2010; Hegazy 2000). An experimental study was performed on a PV/T solar air heater system for indoor conditions (Solanki et al. 2009). It was found that the thermal, electrical, and overall efficiency of the system were $42,8.4$, and $50 \%$, respectively. A comparative study discussed a PV/T system and compared it with a conventional solar water heater and found that the primary energy saving efficiency of the system was about $60 \%$, which is higher than the conventional solar water heater (Huang et al. 2001). A novel PV/T was designed and tested which produced both electricity and hot water (Dubey and Tiwari 2008). An integrated PV and thermal solar water/air-heating system for the conditions of New Delhi was tested (Tiwari and Sodha 2006). They found the thermal efficiency for winter and summer as 77 and $65 \%$, respectively. An experimental study had been carried out on thermosyphon-based PV/T system with and without glass cover (Chow et al. 2009). An experimental study on a sheet and tube-type PV/T system with brine solution as a coolant was also reported in the literature (Saitoh et al. 2003). An experimental study was conducted using water spray to cool both the sides of PV panel (Nizetic et al. 2016a). Their results showed that the PV panel temperature decreased from 54 to $24{ }^{\circ} \mathrm{C}$ and an effective increase in electrical efficiency was measured as $5.9 \%$ with cooling. Two PV panels (poly-Si and mono-Si) were tested numerically and experimentally with the backside convection cooling arrangement for the Mediterranean climatic conditions (Nizetic et al. 2016b). They found out that due to flow separation, there is increase in average panel temperature by $5-9{ }^{\circ} \mathrm{C}$ which results in the degradation of panel electrical efficiency from 2.5 to $4.5 \%$. It is also observed that the efficiency may improve if flow separation is removed.

Other cooling approaches which are used to cool down the system other than PV are also discussed by various researchers. Geothermal cooling is used for air conditioning which is based on the principle that at a depth of about $3.5 \mathrm{~m}$ or more, the soil temperature remains fairly constant throughout the year and is approximately equal to the average annual ambient air temperature (ASHRAE 1985). The concepts of earth air tunnel heat exchanger (EATHE) and earth water heat exchanger (EWHE) for air conditioning using the air and water as a cooling medium have been discussed in the literature (Sodha et al. 1985; Chel et al. 2015; Jakhar et al. 2016a). A numerical model for EATHE was presented and experimentally validated (Bansal et al. 2010). They found that the performance of EATHE does not depend on buried pipe material. The performance of the EATHE was evaluated for winter heating with solar air-heating duct (Jakhar et al. 2015). A one-dimensional heat transfer model of EATHE was developed to calculate the undisturbed temperature of soil, convective heat transfer coefficient of air, diameter of pipe, and pressure drop (Bisoniya 2015). In another study, the applicability of EATHE system for Chandigarh (India) based upon extensive literature review considering the soil properties was reported (Sobti and Singh 2015). 
EWHE systems consist of buried pipe at a certain depth in which hot water is sent, through which heat is dissipated from the hot water to the earth resulting in decrease in the water outlet temperature. Such cooling system using buried pipes can be used for PV-cooling application also. The cooling of PV system has been investigated by many authors using various techniques, such as sheet-in-tube, heat sink, water spray, and parallel channel. However, no one has tried EWHE for the cooling of PV panel. The main objective of the present research work is to numerically investigate the performance of unglazed PV/T coupled with EWHE. For the same, the modeling and simulation of such a coupled system have been done in the transient analysis tool [TRNSYS (v17.0)] for the condition of Pilani, Rajasthan. The performance of this coupled system depends on various parameters which include mass flow rate of the water, pipe material, diameter, and length of pipe and hence evaluated accordingly. This research presents the variation in these parameters to achieve the optimum cooling effect for the PV panels. The proposed system would provide a great opportunity to utilize the geothermal cooling technique for PV cooling in the semi-arid regions of northwestern India, where high ambient temperature during peak summer leaves very small scope for convective cooling with heat rejection to ambient and also minimum scope of utilization of thermal energy.

\section{Description of system and modeling}

As shown in Fig. 1a, the model consists of unglazed PV/T, which is connected to EWHE, through pump and valves in series. The PV/T system is enclosed in a casing and insulated from the sides and back. The copper tubes are mounted on the rear side of PV panel with water as a heat transfer fluid (HTF), as shown in Fig. 1b. The HTF takes away the excess heat from the panels, thus resulting in decrease in cells temperature. The outlet of PV/T is connected to the inlet of EWHE through pipes and valves. In this heat exchanger, the thermal energy is transferred from the hot water (PV/T outlet) to the soil, which is at annual average ambient temperature. The soil acts as a heat sink results in decrease in EWHE outlet temperature, lower than the peak summer ambient temperature. The outlet from the EWHE is then sent back to PV/T inlet through copper tubes for cooling.

Such a proposed system is modeled using the transient analysis tool, TRNSYS v17.0, and simulated as closed loop for $10 \mathrm{~h}$ which is average sunshine hours during summer season. The weather conditions of Pilani, Rajasthan are taken from the inbuilt

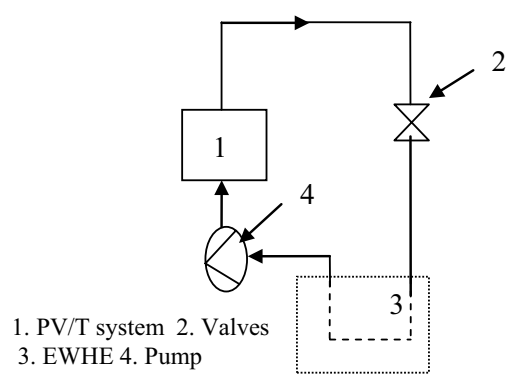

a

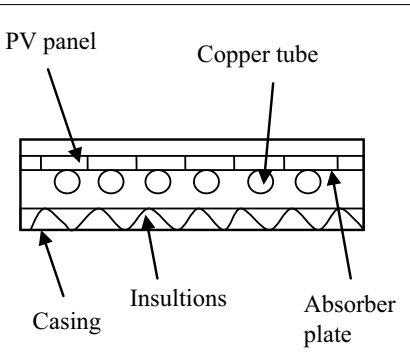

b

Fig. 1 a Schematic diagram of proposed system, $\mathbf{b}$ cross-sectional of unglazed PV/T system 
meteonorm file for the simulation. The couple system is modeled using the library components of the TRNSYS which are also known as Types. For the current system, the following Types were used in the simulation: Type 560-PV/T collector, Type 952-earth water heat exchanger, Type 15-weather data processor, Type 3-variable speed pump, Type 2-controller, and Type 65-online plotter. Different parameters which are taken as input for the simulation are shown in Table 1.

\section{Methods}

The methodology of system design and its parametric variation for the EWHE is discussed in this section. The simulation of PV/T coupled with EWHE system is carried out for $10 \mathrm{~h}$ of system operation which is average sunshine hours as a conservative estimate during peak summer period (June 21). To optimize the design parameters of such a coupled system, the parametric simulation was performed for different mass flow rates for a fixed diameter and length of the high-density polyethylene (HDPE) pipe. This analysis gives the optimum flow rate $(0.018 \mathrm{~kg} / \mathrm{s})$ for a $30 \mathrm{~m}$ HDPE pipe length and diameter of $12 \mathrm{~mm}$. For three different EWHE pipe materials, i.e., galvanized iron (GI), HDPE, and steel pipe, the simulation was carried out that it shows that the performance of the coupled system hardly depends on the buried pipe material. Thus, among all the pipe materials discussed here, HDPE pipe is considered for the performance analysis, as it is economical as compared to other two. With HDPE as pipe material, variation in pipe length is analysed for a particular diameter and flow rate. Furthermore, the variation in pipe diameter is carried out by keeping pipe length and mass flow rate constant.

\section{Results and discussion}

The performance of EWHE and PV/T system is analysed by varying different parameters, which includes the type of pipe material, length, diameter of pipe, and mass flow rate of water. The effect of mass flow rate on the performance of PV/T along the EWHE pipe length of $30 \mathrm{~m}$ and diameter of $25 \mathrm{~mm}$ for the HDPE pipe is shown in Fig. 2. It reveals that the temperature of PV goes up to $79.31{ }^{\circ} \mathrm{C}$ without any cooling. In the case of EWHE cooling scenario, the PV temperature decreases significantly and it varies with

Table 1 Physical and thermal parameters used in the simulation

\begin{tabular}{ll}
\hline Parameters & Properties \\
\hline PV/T collector length & $1.20 \mathrm{~m}$ \\
PV/T collector width & $1.59 \mathrm{~m}$ \\
Thermal conductivity of absorber plate & $385 \mathrm{~W} / \mathrm{m} \mathrm{K}$ \\
Copper tube diameter (OD) & $0.012 \mathrm{~m}$ \\
PV efficiency at reference condition & $12 \%$ \\
PV panel reference temperature & $25^{\circ} \mathrm{C}$ \\
HDPE pipe thermal conductivity & $0.40 \mathrm{~W} / \mathrm{m} \mathrm{K}$ \\
Galvanized Iron (Gl) pipe thermal conductivity & $16 \mathrm{~W} / \mathrm{m} \mathrm{K}$ \\
Steel pipe thermal conductivity & $54 \mathrm{~W} / \mathrm{m} \mathrm{K}$ \\
Fluid density & $1000 \mathrm{~kg} / \mathrm{m}^{3}$ \\
Fluid thermal conductivity & $0.55 \mathrm{~W} / \mathrm{m} \mathrm{K}$ \\
Buried pipe depth & $3.5 \mathrm{~m}$
\end{tabular}




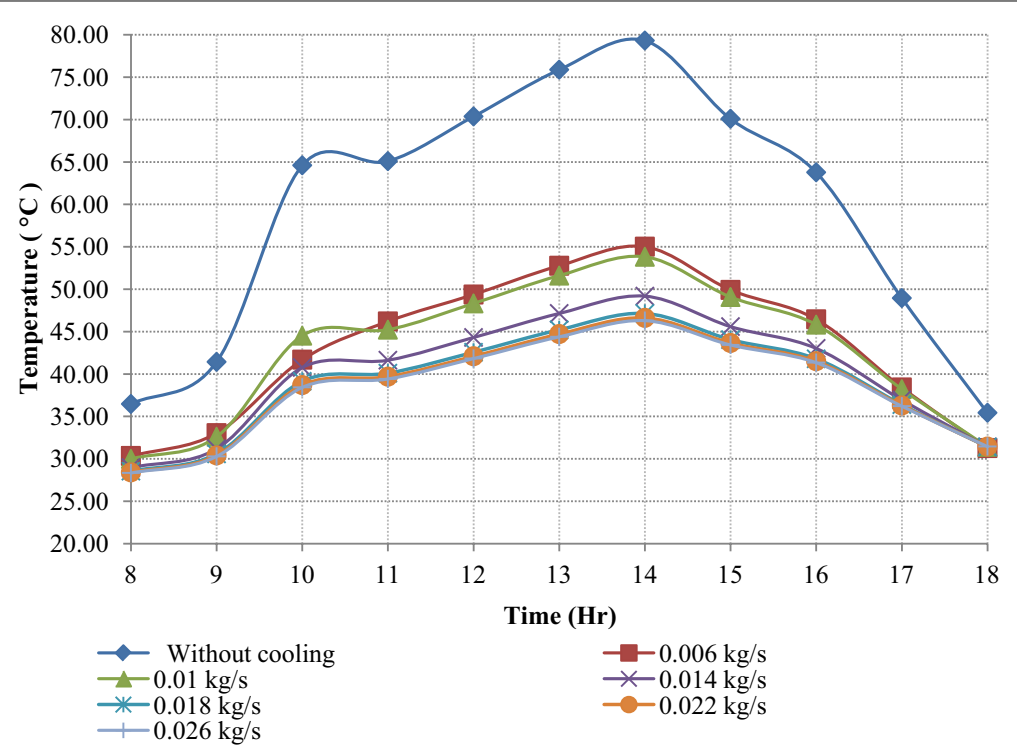

Fig. 2 PV temperature with cooling and without cooling for various mass flow rates (pipe $\phi 12 \mathrm{~mm}$, length $=30 \mathrm{~m}$, HDPE pipe)

different mass flow rates, i.e., $29.99-53.82{ }^{\circ} \mathrm{C}$ for $0.01 \mathrm{~kg} / \mathrm{s}, 28.54-47.13^{\circ} \mathrm{C}$ for $0.018 \mathrm{~kg} / \mathrm{s}$, and $28.33-46.29{ }^{\circ} \mathrm{C}$ for $0.026 \mathrm{~kg} / \mathrm{s}$. It is observed that with increase in mass flow rate, the PV temperature decreases and becomes almost the same for $0.018,0.022$, and $0.026 \mathrm{~kg} / \mathrm{s}$. For the practical applications, $0.018 \mathrm{~kg} / \mathrm{s}$ flow rate could be used as with increase in mass flow rate, the pumping power required also increases. Figure 3 shows the PV temperature for three different EWHE pipe materials (i.e., GI, HDPE, and steel) for the diameter and length of $12 \mathrm{~mm}$ and $30 \mathrm{~m}$, respectively, with the flow rate of $0.018 \mathrm{~kg} / \mathrm{s}$. It reveals that the temperature difference of PV for HDPE and GI is mere $1.04{ }^{\circ} \mathrm{C}$, while in the steel and HDPE pipe is around $1.5{ }^{\circ} \mathrm{C}$, for the same simulation conditions. Figure 4 shows the PV power output for three different pipe materials for the flow rate of $0.018 \mathrm{~kg} / \mathrm{s}$. It is observed from Fig. 4 that the difference in power output is just $0.97 \mathrm{~W}$ for HDPE and steel pipe, here in the analysis, power consumed by pump is not considered. This

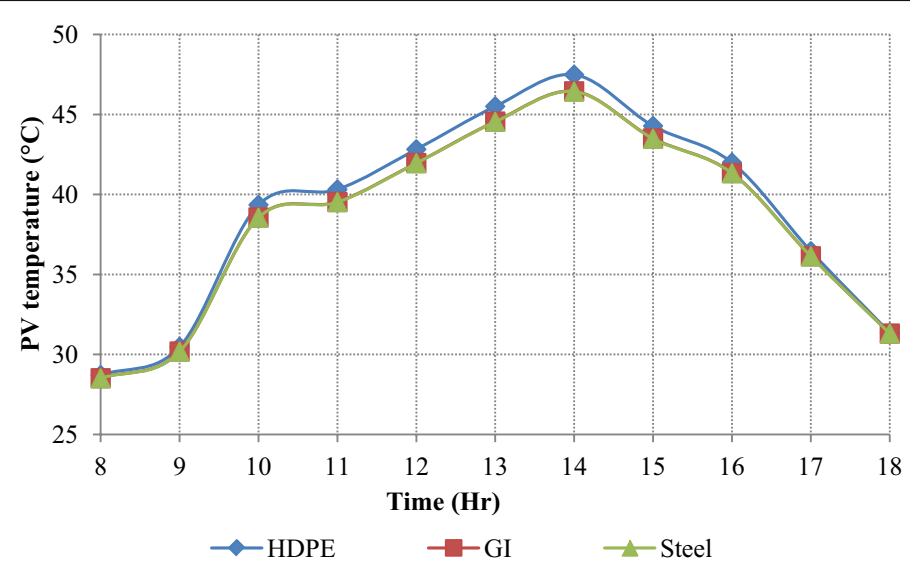

Fig. 3 PV temperature vs. different pipe materials (pipe $\phi 12 \mathrm{~mm}$, length $=30 \mathrm{~m}$, flow rate $=0.018 \mathrm{~kg} / \mathrm{s}$ ) 


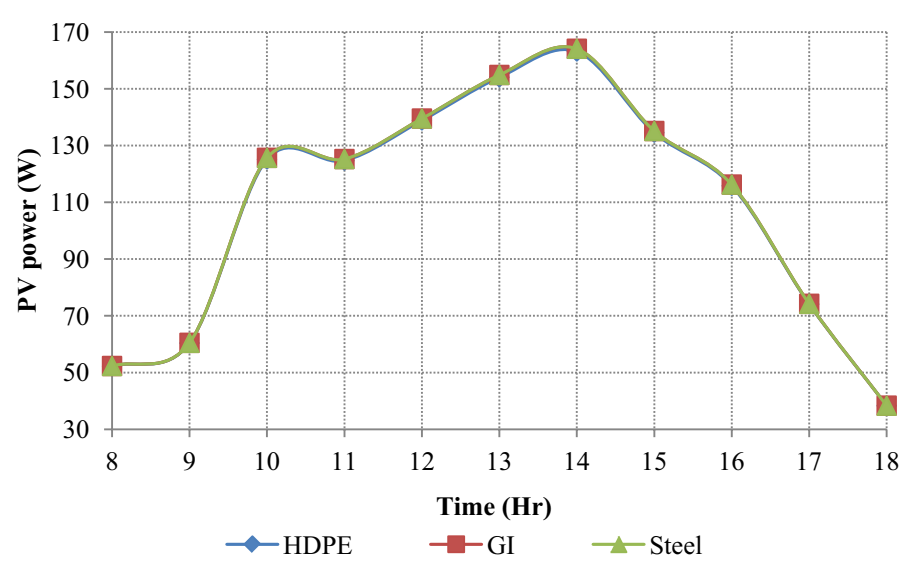

Fig. 4 PV power vs. different pipe materials (pipe $\phi 12 \mathrm{~mm}$, length $=30 \mathrm{~m}$, flow rate $=0.018 \mathrm{~kg} / \mathrm{s}$ )

small variation is due to small coefficient of friction and lower thermal conductivity of HDPE pipes, while that of higher thermal conductivity and higher coefficient of friction for steel and GI. The higher heat transfer due to one better property is compensated by another poor property. Hence, there is marginal variation in the outlet temperature and power output for all the three materials. Thus, it can be concluded that the selection of pipe materials out of three materials has a small impact on the performance of the PV/T-coupled EWHE system. The same has also been discussed in the literature for EATHE (Bansal et al. 2010). This validates the selection of the HDPE pipe, as it is much cheaper than the other two.

Furthermore, the hourly variation of PV temperature is estimated for the different pipe lengths for HDPE pipe diameter $(12 \mathrm{~mm})$ and flow rate of $0.018 \mathrm{~kg} / \mathrm{s}$ and has been represented in Fig. 5. From Fig. 5, it is observed that the PV temperature decreases with increase in pipe length from 10 to $60 \mathrm{~m}$. It also observed that during peak sunshine hour, for the pipe length up to $50 \mathrm{~m}$, the maximum PV temperature drops drastically, and with increase in pipe length beyond $50 \mathrm{~m}$, this temperature drop is gradually. From Fig. 6, it is observed that for variation in pipe length from 10 to $50 \mathrm{~m}$, the maximum PV power

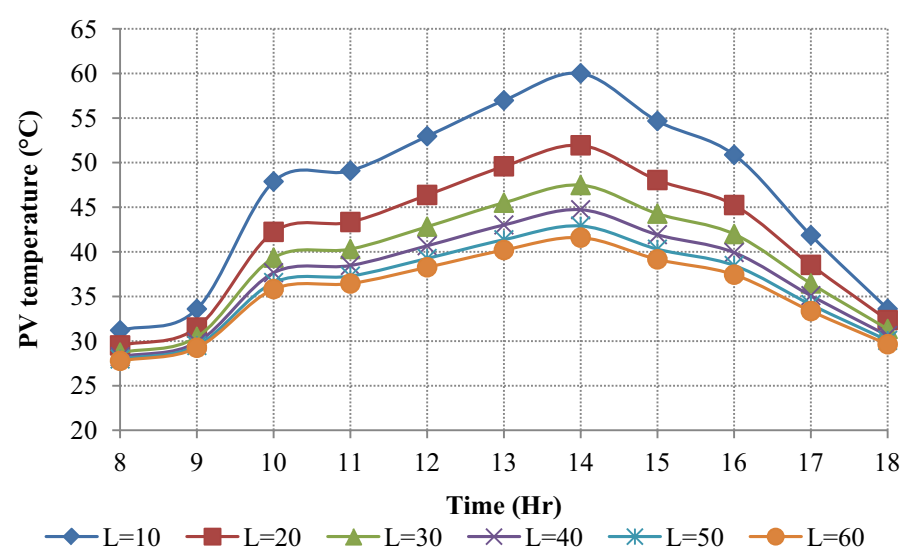

Fig. 5 PV temperature vs. different pipe lengths (pipe $\phi 12 \mathrm{~mm}$, flow rate $=0.018 \mathrm{~kg} / \mathrm{s}$, pipe material $=$ HDPE) 


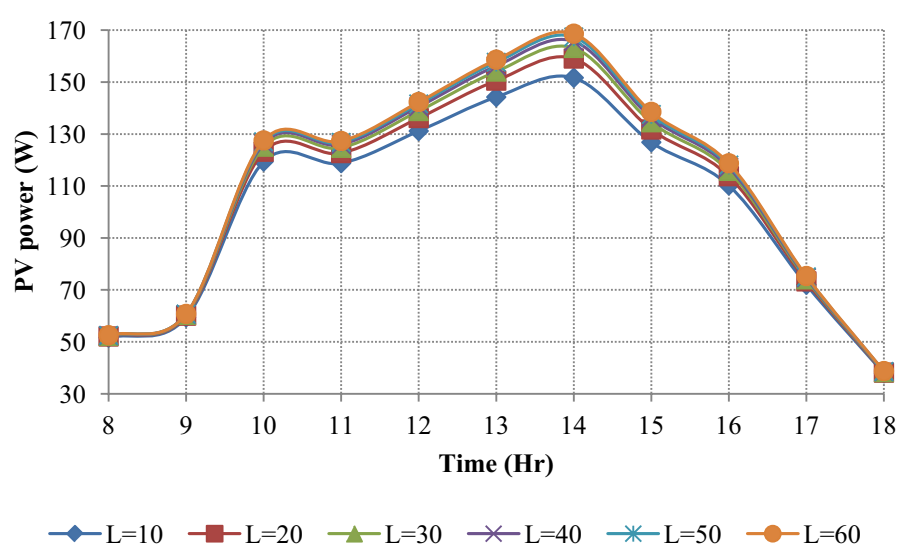

Fig. 6 PV power vs. different pipe lengths (pipe $\phi 12 \mathrm{~mm}$, flow rate $=0.018 \mathrm{~kg} / \mathrm{s}$, pipe material $=$ HDPE)

ranges from 151.64 to $167.36 \mathrm{~W}$ at peak sunshine hour. However, for the pipe length of $60 \mathrm{~m}$, the maximum PV power is $168.60 \mathrm{~W}$, which is just $1.24 \mathrm{~W}$ increase in power output for $10 \mathrm{~m}$ increase in pipe length as compared to $50 \mathrm{~m}$. Thus, the pipe length of $50 \mathrm{~m}$ would be sufficient for such coupled systems.

The variation of PV temperature with respect to time for various diameters with the flow rate of $0.018 \mathrm{~kg} / \mathrm{s}$ and pipe length of $50 \mathrm{~mm}$ is represented in Fig. 7. With increase in the pipe diameter, the PV temperature decreases gradually over a period of time. Initially, during the first hour of simulation, the PV temperature drop is less for smaller diameters, while it is more in the case of larger diameters. At the peak simulation hour, the PV temperature in all the pipe diameters exhibits almost similar temperature drop, with the variation of just $1.05{ }^{\circ} \mathrm{C}$ between 12 and $25 \mathrm{~mm}$ pipe diameters. Figure 8 shows the variation of PV power output with respect to time for various pipe diameters with the flow rate of $0.018 \mathrm{~kg} / \mathrm{s}$ and the pipe length of $50 \mathrm{~m}$. It is observed that at $1400 \mathrm{~h}$, for 12 and $25 \mathrm{~mm}$ pipe diameter, PV power output is 167.36 and $168.30 \mathrm{~W}$, respectively, which is a very small variation. From the analysis and the figures, it is observed that the variation in pipe diameters hardly affects the PV power output. Thus, it is concluded

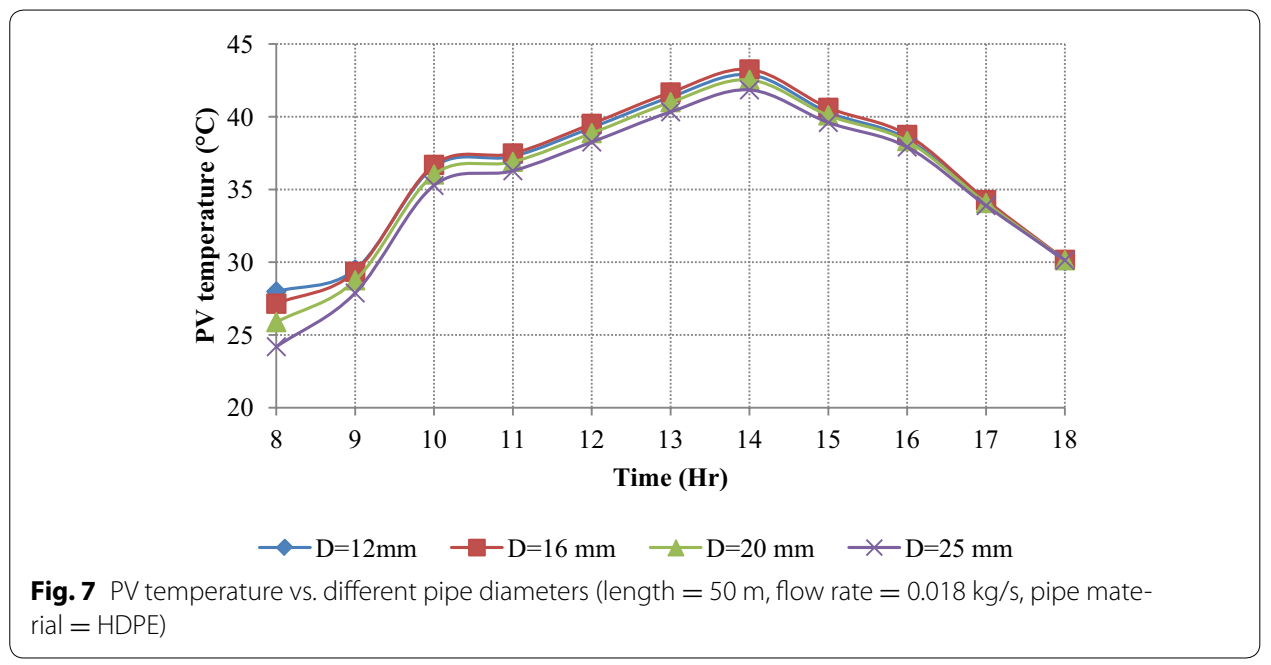




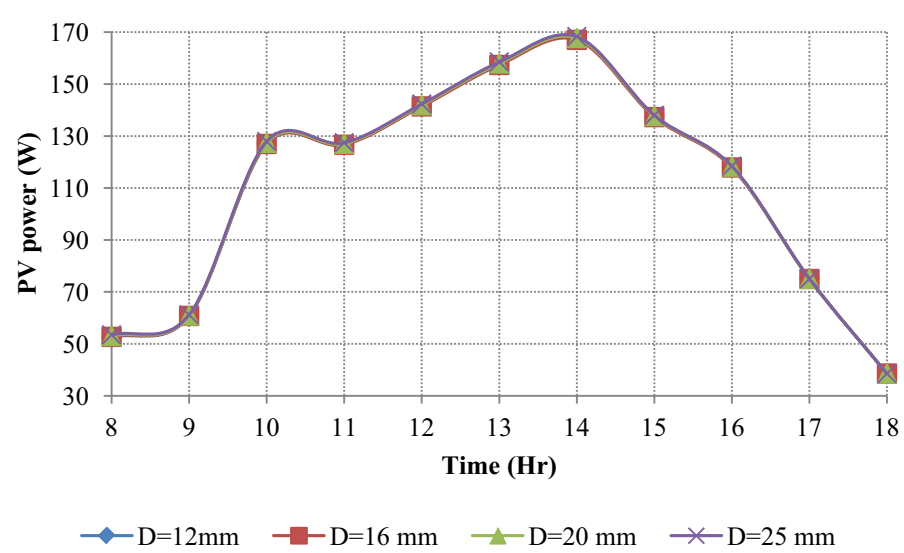

Fig. 8 PV power vs. different pipe diameters (length $=50 \mathrm{~m}$, flow rate $=0.018 \mathrm{~kg} / \mathrm{s}$, pipe material $=$ HDPE)

that $12 \mathrm{~mm}$ pipe may be considered for the practical applications because of economic reasons. The analysis of results of TRNSYS simulation of PV/T coupled with EWHE system as discussed above provides the optimum values of various parameters.

The variation of all the parameters combined together is represented in 3D surface plot using MATLAB and represented in Figs. 9 and 10. The variation in PV cell temperature with respect to variation in pipe diameter, pipe length, and mass flow rates is shown in Fig. 9. The comparative variation shows the direct correlation of each parameter with respect to PV cell temperature. Similar to this, another 3D surface plot has been mapped in Fig. 10 which depicts the variation in PV power output with respect to variation in pipe diameter, pipe length, and flow rates. It is observed that there is marginally temperature variation and power output for the flow rate of $0.022 \mathrm{~kg} / \mathrm{s}$, pipe diameter of $25 \mathrm{~mm}$ and pipe length of $60 \mathrm{~m}$ as compared to flow rate of $0.018 \mathrm{~kg} / \mathrm{s}$, pipe diameter of $12 \mathrm{~mm}$, and pipe length of $50 \mathrm{~m}$. Thus, the later case may be considered for practical application owing to economical reason.

From the literature review, it is observed that there is hardly any single study on $\mathrm{PV} / \mathrm{T}$ coupled with EWHE using water as a heat transfer fluid. Studies on various PV/T
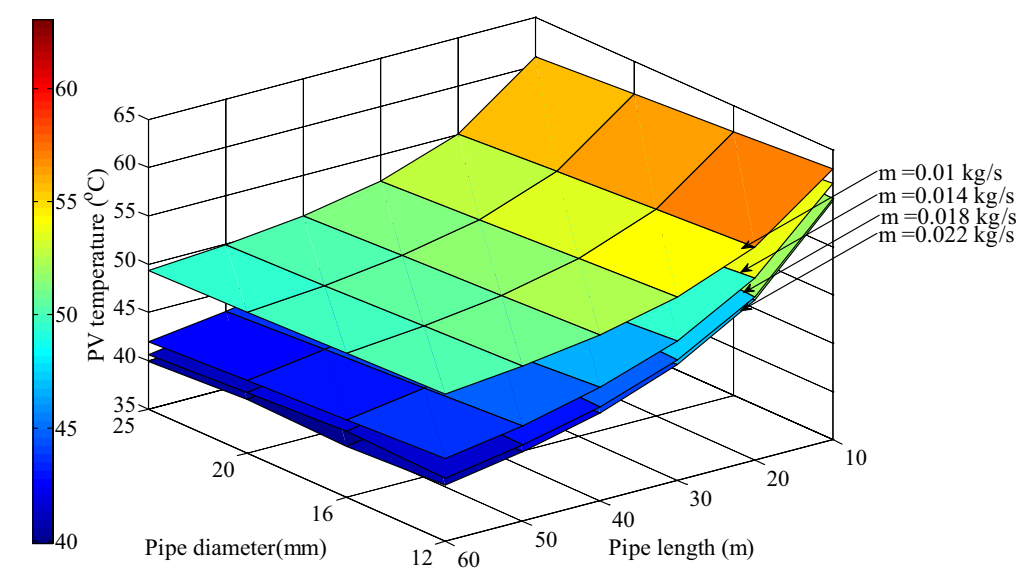

Fig. 9 PV temperature for different mass flow rates at different pipe diameters and lengths (material = HDPE) 


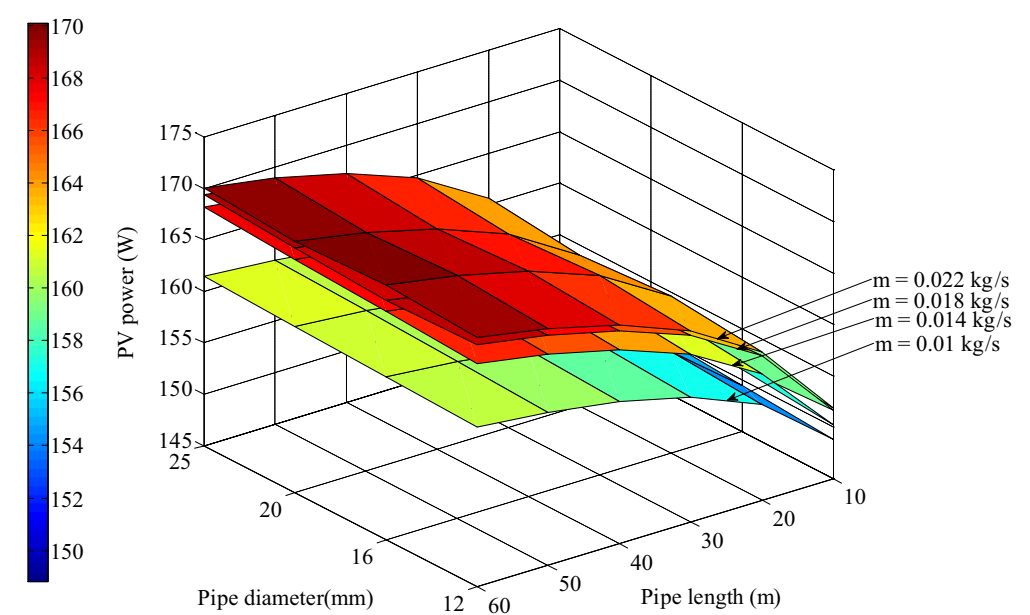

Fig. 10 PV power for different mass flow rates at different pipe diameters and lengths (material = HDPE)

systems and their applications vary and depend on the ambient condition, solar radiation, wind velocity, etc. Hence, it would be difficult to compare them on a common basis. Similarly, studies based on EWHE depend on soil properties and the location thus cannot be generalized. Moreover, a sufficient amount of research has been done on EATHE. Some researchers have done work using EATHE for air conditioning. One of the experimental studies was performed on the hybrid EATHE (Misra et al. 2013) for the conditions of Ajmer (India). In their experimental analysis, they used the thermal and physical parameters of various materials, such as soil density, soil thermal conductivity, soil specific heat, and pipe thermal conductivity as $2050 \mathrm{~kg} / \mathrm{m}^{3}, 0.52 \mathrm{~W} / \mathrm{mK}, 1.840 \mathrm{~kJ} / \mathrm{kg} \mathrm{K}$, and $0.16 \mathrm{~W} / \mathrm{mK}$, respectively. Experimental study done by Misra et al. 2013 is simulated in TRNSYS on a model of EATHE to determine the precision of results for the same properties of materials. The variation of EATHE outlet air temperature with the length of EATHE pipe from both the simulation and experimental analyses is shown in Fig. 11. It is observed from Fig. 11 that the simulated results are within the close agreement with

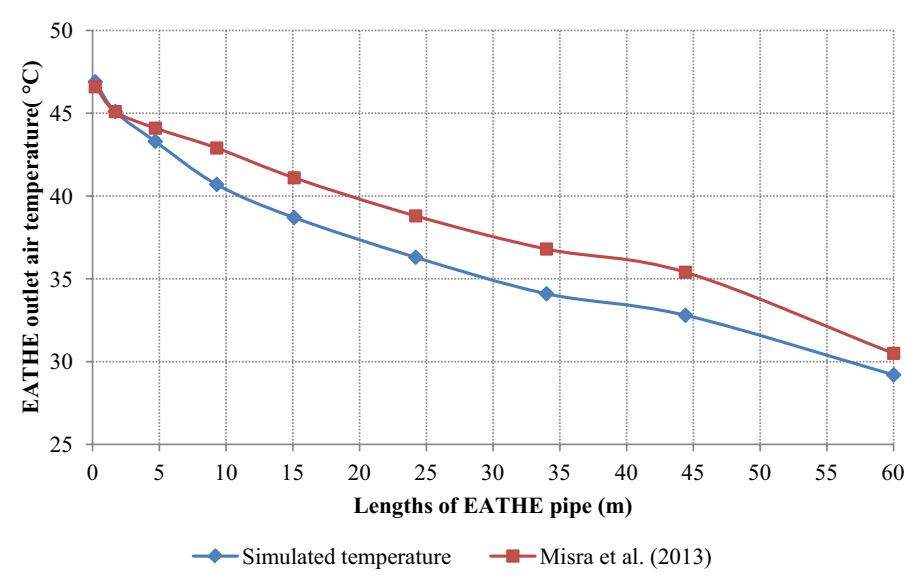

Fig. 11 Simulated EATHE model validation with experimental results in the literature (Misra et al. 2013) 
the experimental results with the variation of $0.8-7.93 \%$. This error may occur due to the improper insulation of pipes, variation in coefficient of friction of materials used in the simulation, and irregularities, such as fitting and joints in the experimental setup. Therefore, the comparison of the simulated model and experimental results in the literature with the air; as heat transfer fluid is showing small error for the same climatic conditions, it is expected that the study for the EWHE will also follow the same pattern with more precise results. Thus, the coupled system of EWHE and PV/T would provide better results in the present simulation.

The climatic condition for the simulation of the coupled system is taken as that of Pilani, Rajasthan which has semi-arid climate and has high ambient air temperature and high solar radiation during peak summer day (21 June, equinox day) and is shown in Fig. 12. It reveals that the ambient temperature and solar radiation range between 239-997.58 W/ $/ \mathrm{m}^{2}$ and $33.40-39.58^{\circ} \mathrm{C}$, respectively, for the Pilani, Rajasthan. Figure 12 also shows the climatic data for the Jodhpur, Rajasthan and reveals that the solar radiation and ambient temperature vary between 261.70 and $987.90 \mathrm{~W} / \mathrm{m}^{2}$, and 33.50 and $43.40{ }^{\circ} \mathrm{C}$, respectively. For an additional climatic information of western India, Fig. 13 shows the solar insolation and ambient temperature for the conditions of Bhuj and Ahmedabad (Gujarat). It is observed that maximum solar insolation and ambient temperature go up to $908.73 \mathrm{~W} / \mathrm{m}^{2}$ and $40.89{ }^{\circ} \mathrm{C}$, respectively. Since, the Rajasthan and Gujarat states have good solar insolation throughout the year, the technique of PV-cooling system with EWHE can prove to be suitable technique in specially arid region and when peak summer temperatures are about $45^{\circ} \mathrm{C}$. The weather conditions of Rajasthan and Gujarat are taken from the inbuilt meteornorm file in the TRNSYS.

\section{Conclusion}

The present paper discusses the analysis of unglazed PV/T-coupled EWHE system by varying different parameters, such as buried pipe diameter, pipe material, pipe length, and flow rate. The system is designed and simulated using the TRNSYS (v17.0) software for the conditions of Pilani, Rajasthan during peak summer day (21 June). The performance of such a system for various pipe materials, i.e., GI, HDPE, and steel, is compared.

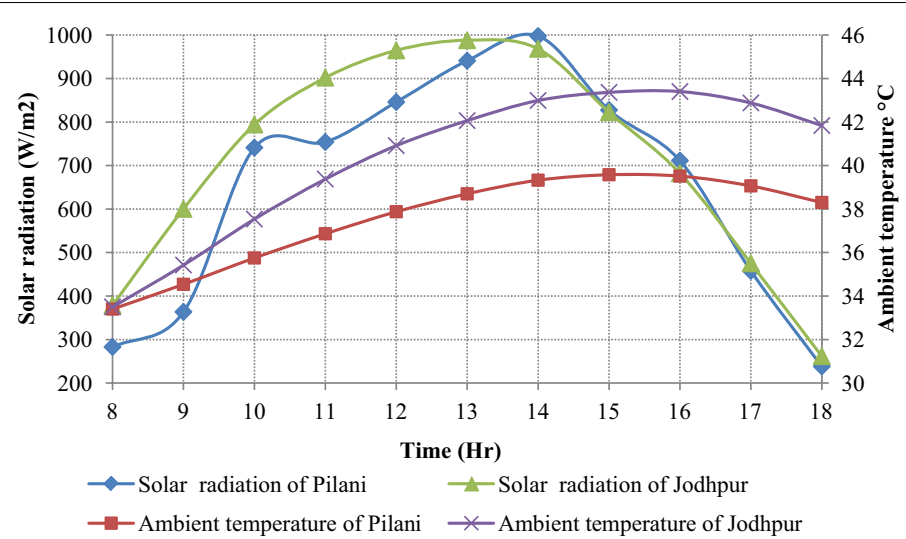

Fig. 12 Intensity of solar radiation and ambient air temperature of June, 21 for the Pilani and Jodhpur (Rajasthan) 


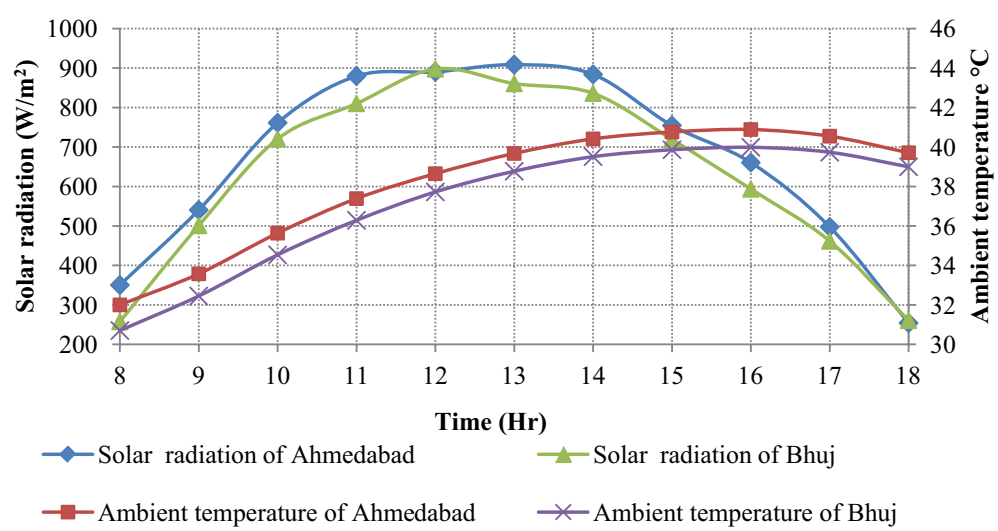

Fig. 13 Intensity of solar radiation and ambient air temperature of June, 21 for the Ahmedabad and Bhuj (Gujarat)

From the analysis, it is observed that there is marginally variation in the performance of the system for different pipe materials. Therefore, it is concluded that among three materials which are considered for the analysis, HDPE pipe may be used for practical applications because of economical reason. From the simulation results of variation in pipe lengths, it is observed that with increase in pipe length, the PV temperature decreases and power output increases. Results showed that maximum drop in PV temperature has observed from 10 to $50 \mathrm{~m}$ length as $60-42.89^{\circ} \mathrm{C}$. However, for the length of $60 \mathrm{~m}$, the PV temperature is $41.59{ }^{\circ} \mathrm{C}$ which is little higher as compared to $50 \mathrm{~m}$ pipe length. Similar trend has been observed for the PV power output. Hence, the pipe length of $50 \mathrm{~m}$ will be sufficient for the system. Further analysis shows that with increase in the pipe diameter, the outlet temperature decreases gradually over a period of time, but at the peak simulation hour, the PV temperature for all the pipe diameters exhibits similar temperature drop. Thus, smaller pipe diameter, i.e., $12 \mathrm{~mm}$, may be used for the practical applications. Therefore, finally, it is concluded that this combined system may be a better solution for rejecting the excess heat of PV panels for the semi-arid northwestern regions of India which are blessed with high solar insolation throughout the year.

\section{Authors' contributions}

All authors contributed according to their respective areas of expertise and experience for the parametric study of the present research. SJ carried out the literature review of the relevant research papers, identified the key parameters to optimized, performed modeling and simulation, and drafted the manuscript. MSS suggested the paper alignment, content of the paper, and proofread the draft. NG suggested the graphical representation and proofread the draft. All authors read and approved the final manuscript.

Acknowledgements

Authors gratefully acknowledge the support from the Center for Renewable Energy and Environment Development, Birla Institute of Technology and Science, Pilani, Rajasthan, for this research.

Competing interests

The authors declare that they have no competing interests.

Received: 26 June 2016 Accepted: 8 September 2016

Published online: 16 September 2016 
References

ASHRAE. Handbook of application. Atlanta Ga: American Society of Heating Refrigerating and Air Conditioning engineers Inc; 1985.

Bansal V, Misra R, Agrawal G Das, Mathur J. Performance analysis of earth-pipe-air heat exchanger for summer cooling. Energy Build. 2010;42(5):645-8.

Bisoniya TS. Design of earth-air heat exchanger system. Geotherm Energy. 2015;3(18):1.

Cabo FG, Nizetic S, Marco TG. Photovoltaic panels: a review of the cooling techniques. Trans FAMENA. 2016;40(S1-1):63-74.

Chel A, Janssens A, Paepe M De. Thermal performance of a nearly zero energy passive house integrated with the air-air heat exchanger and the earth-water heat exchanger. Energy Build. 2015;96:53-63.

Chow TT. A review on photovoltaic/thermal hybrid solar technology. Appl Energy. 2010;87(2):365-79.

Chow TT, Pei G, Fong KF, Lin Z, Chan AL, Ji J. Energy and exergy analysis of photovoltaic-thermal collector with and without glass cover. Appl Energy. 2009;86(3):310-6. doi:10.1016/j.apenergy.2008.04.016.

Du D, Darkwa J, Kokogiannakis G. Thermal management systems for photovoltaics (PV) installations: A critical review. Sol Energy. 2013;97:238-54. doi:10.1016/j.solener.2013.08.018.

Dubey S, Tiwari GN. Thermal modeling of a combined system of photovoltaic thermal (PV/T) solar water heater. Sol Energy. 2008;82(7):602-12.

Gakkhar N, Soni MS, Jakhar S. Second law thermodynamic study of solar assisted distillation system: a review. Renew Sustain Energy Rev. 2016;56:519-35.

Hegazy AA. Comparative study of the performances of four photovoltaic/thermal solar air collectors. Energy Convers Manag. 2000;41(8):861-81.

Huang BJ, Lin TH, Hung WC, Sun FS. Performance evaluation of solar photovoltaic/thermal system. Sol Energy. 2001;70(5):443-8.

Jakhar S, Misra R, Bansal V, Soni MS. Thermal performance investigation of earth air tunnel heat exchanger coupled with a solar air heating duct for northwestern India. Energy Build. 2015;87:360-9.

Jakhar S, Misra R, Soni MS, Gakkhar N. Parametric simulation and experimental analysis of earth air heat exchanger with solar air heating duct. Eng Sci Technol Int J. 2016a;19(2):1059-66. doi:10.1016/j.jestch.2016.01.009.

Jakhar S, Soni MS, Gakkhar N. Historical and recent development of concentrating photovoltaic cooling technologies. Renew Sustain Energy Rev. 2016b;60:41-59.

Jakhar S, Soni MS, Gakkhar N. Performance analysis of photovoltaic panels with earth water heat exchanger cooling. MATEC Web Conf. 2016c;55:1-6.

Misra R, Bansal V, Agarwal GD, Mathur J, Aseri T. Evaluating thermal performance and energy conservation potential of hybrid earth air tunnel heat exchanger in hot and dry climate-in situ measurment. J Therm Sci Eng Appl. 2013;5(3):031006.

Nizetic S, Coko D, Yadav A, Cabo FG. Water spray cooling technique applied on a photovoltaic panel: the performance response. Energy Convers Manag. 2016a;108:287-96.

Nizetic S, Cabo FG, Kragic IM, Papadopoulos AM. Experimental and numerical investigation of a backside convective cooling mechanism on photovoltaic panels. Energy. 2016b;111:211-25.

Ozgoren M, Aksoy MH, Bakir C, Dogan S. Experimental Performance Investigation of Photovoltaic/Thermal (PV-T) System. In: EPJ Web of Conferences 2013; 45:01106.

Royne A, Dey CJ, Mills DR. Cooling of photovoltaic cells under concentrated illumination: a critical review. Sol Energy Mater Sol Cells. 2005;86(4):451-83.

Sobti J, Singh SK. Earth-air heat exchanger as a green retrofit for Chandigarh-a critical review. Geotherm Energy. 2015;3(14):1.

Saitoh H, Hamada Y, Kubota H, Nakamura M, Ochifuji K, Yokoyama S, Nagano K. Field experiments and analyses on a hybrid solar collector. Applied Thermal Engineering. 2003;23(16):2089-105. doi:10.1016/S1359-4311(03)00166-2.

Sodha MS, Sharma AK, Singh SP, Bansal NK, Kumar A. Evaluation of an earth-air tunnel system for cooling/heating of a hospital complex. Build Environ. 1985;20(2):115-22.

Solanki SC, Dubey S, Tiwari A. Indoor simulation and testing of photovoltaic thermal (PV/T) air collectors. Appl Energy. 2009:86(11):2421-8.

Tiwari A, Sodha MS. Performance evaluation of hybrid PV/thermal water/air heating system: A parametric study. Renew Energy. 2006;31(15):2460-74. doi:10.1016/j.renene.2005.12.002.

Ummadisingu A, Soni MS. Concentrating solar power-technology, potential and policy in India. Renew Sustain Energy Rev. 2011;15(9):5169-75

\section{Submit your manuscript to a SpringerOpen ${ }^{\circ}$ journal and benefit from:}

- Convenient online submission

- Rigorous peer review

- Immediate publication on acceptance

- Open access: articles freely available online

- High visibility within the field

- Retaining the copyright to your article

Submit your next manuscript at $\gg$ springeropen.com 